\title{
Preparation of antiviral sera for immunofluorescence on infected tissue culture
}

\author{
SUSAN HERD AND KATHLEEN MACWILLIAM \\ From the Department of Virology, The Wright-Fleming Institute, St. Mary's Hospital Medical School, \\ Paddington, London
}

SYNOPSIS Antisera were prepared in rabbits against parainfluenza types 1, 2, and 3, respiratoryi syncytial, herpes, and adenoviruses, either by intranasal administration or by injection of virust grown in $\mathbf{R K}_{13}$ cells. These antisera gave satisfactory results when used for immunofluorescence $\omega$ by the indirect method on virus in tissue culture. No absorption of the antiviral serum was carried out.

The indirect technique for fluorescent antibody staining needs only one fluorescent conjugate to demonstrate several viruses, and is more sensitive than the direct method. For use in diagnostic laboratories, therefore, where the need is for identification of several viruses, the indirect method would seem to be the one of choice if suitable antiviral sera and fluorescent conjugates are available.

A commercially manufactured fluorescein conjugated antirabbit globulin from Baltimore Biological Laboratories was found to be satisfactory and was used for the study. Antiviral sera were therefore prepared in rabbits. The requirements of these antiviral sera are a reasonable viral antibody titre, a low tissue antibody, and a low non-specific reaction. Non-specificity and tissue antibody can be largely eliminated by absorption (Coons and Kaplan, 1950), but to save another technical procedure the present paper investigates the possibility of producing sera sufficiently specific for use without absorption.

Three methods were tried: first, growth of virus in tissue of the same species as the animal used for preparation of antisera (in this case $\mathrm{RK}_{\mathbf{1 3}}$ a continuous line of rabbit kidney cells); secondly, administration of virus intranasally as suggested by Hambling (1966); and thirdly, growth of virus in tissue unrelated to that used for diagnostic isolation.

\section{Methods}

GROWTH AND PREPARATION OF VIRUS Most of the viruses grew fairly well in the tissues Received for publication 16 September 1970. selected. Respiratory syncytial virus was adapted to$\mathbf{R K}_{13}$ cells by a method to be described elsewhere. L132 is a line of human lung cells, for which we are indebted to Dr Bradburne of the Common Coldo Research Unit.

Virus was obtained from respiratory syncytial, herpes, and mumps virus cultures by scraping cellsŏ off into the medium, treating the suspension in an ultrasonic bath for $30 \mathrm{sec}$, and centrifuging at $1,550 \mathrm{~g}$ for five minutes. The supernatant fluids 3 from cultures of parainfluenza virus were centrifuged, and adenovirus cultures were frozen and thawedo six times and centrifuged.

Virus given intranasally received no additional? treatment. Virus given by injection was shaken with an equal volume of arcton 113 (ICI) and allowed to settle at room temperature.

IMMUNIZATION OF RABBITS

A summary of the schedules used for immunization $\frac{D}{O}$ is shown in Table I. For intranasal inoculation the animals were anaesthetized with intravenous nem- $N$ butal and virus was dropped into the nose from $a_{N}$ $1 \mathrm{ml}$ disposable syringe. Intravenous injections were $\mathrm{N}$ given into an ear vein.

TISSUE CULTURE

Synthetic medium 199 was used throughout. For ${ }_{\mathscr{D}}^{\bar{\Phi}}$ $\mathrm{Hep}_{2}$ and L132, $0.13 \%$ sodium bicarbonate and ${ }^{++}$ $10 \%$ calf serum were added for growth, and $0.13 \% \frac{0}{0}$ sodium bicarbonate and $2 \%$ foetal calf serum for maintenance. For $\mathbf{R K}_{13}$ cells rabbit serum was $\frac{?}{\Phi}$ substituted for calf and foetal calf serum. Monkey@ kidney was grown on 199 with $10 \%$ calf serum and $0.088 \%$ sodium bicarbonate and maintained with $\varrho$ 


\begin{tabular}{|c|c|c|c|c|c|c|}
\hline Virus & Rabbit No. & Virus Grown in & $\begin{array}{l}\text { Interval } \\
\text { between Doses }\end{array}$ & Dose No. & $\begin{array}{l}\text { Dose of Virus } \\
\left(T C D_{50} / \mathrm{ml}\right)\end{array}$ & $\begin{array}{l}\text { Route of } \\
\text { Administration }\end{array}$ \\
\hline Parainfluenza type 1 & 1 & $\begin{array}{l}\text { MK } \\
\text { Eggs }\end{array}$ & $11 \mathrm{wk}$ & $\begin{array}{l}1 \\
2\end{array}$ & $\begin{array}{l}1 \times 10^{8.5} \\
1 \times 10^{9.5}\end{array}$ & $\begin{array}{l}\text { Intranasal } \\
\text { Intranasal }\end{array}$ \\
\hline Parainfluenza type 2 & 2,3 & L132 & 4 wk & 1 & $\begin{array}{l}2 \times 10^{7.5} \\
2 \times 10^{7.5}\end{array}$ & $\begin{array}{l}\text { Intranasal } \\
\text { Intranasal }\end{array}$ \\
\hline Parainfluenza type 3 & 4,5 & $\mathrm{RK}_{13}$ & 4 wk & 1 & $\begin{array}{l}1 \times 10^{7.5} \\
5 \times 10^{7.5}\end{array}$ & $\begin{array}{l}\text { Intranasal } \\
\text { Intranasal }\end{array}$ \\
\hline Respiratory syncytial & 6,7 & $\mathrm{Hep}_{2}$ & 2 wk & $\begin{array}{l}1 \\
2\end{array}$ & $\begin{array}{l}4 \times 10^{7 \cdot 3} \\
1 \times 10^{6.5}\end{array}$ & $\begin{array}{l}\text { Intranasal } \\
\text { Intranasal }\end{array}$ \\
\hline Respiratory syncytial & 8,9 & $\mathbf{R K}_{13}$ & 2 wk & 1 & $\begin{array}{l}5 \times 10^{5.5} \\
5 \times 10^{6.0}\end{array}$ & $\begin{array}{l}\text { Intravenous } \\
\text { Intravenous }\end{array}$ \\
\hline Adeno type 5 & 10,11 & $\mathbf{R K}_{13}$ & 9 days & $\begin{array}{l}1 \\
2\end{array}$ & $\begin{array}{l}5 \times 10^{7 \cdot 0} \\
5 \times 10^{7.5} \\
2 \times 10^{7.5}\end{array}$ & $\begin{array}{l}\text { Intravenous } \\
\text { Intravenous } \\
\text { Subcutaneous } \perp \\
\text { F.C.A. }{ }^{1}\end{array}$ \\
\hline Herpes simplex type I & 12,13 & $\mathbf{R K}_{13}$ & 12 days & $\begin{array}{l}1 \\
2\end{array}$ & $\begin{array}{l}0.5 \times 10^{6.0} \\
5 \times 10^{6.5}\end{array}$ & $\begin{array}{l}\text { Subcutaneous } \\
\text { Intravenous }\end{array}$ \\
\hline Mumps & 14,15 & $\mathrm{Hep}_{2}$ & 2 wk & $\begin{array}{l}1 \\
2\end{array}$ & $\begin{array}{l}5 \times 10^{5.5} \\
5 \times 10^{6.0}\end{array}$ & $\begin{array}{l}\text { Intravenous } \\
\text { Intravenous }\end{array}$ \\
\hline
\end{tabular}

Table 1 Schedule for immunization of rabbits

${ }^{1}$ Freund's complete adjuvant.

$0.088 \%$ sodium bicarbonate and $0.5 \%$ foetal calf serum. Penicillin 100 units $/ \mathrm{ml}$, streptomycin $0 \cdot 1$ $\mathrm{mg} / \mathrm{ml}$, nystatin 25 units $/ \mathrm{ml}$, and tylosin $0.01 \mathrm{mg} / \mathrm{ml}$ were also added. Virus used for immunization was normally changed to serum-free medium.

\section{STAINING}

Virus of suitable concentration was grown overnight in tissue on $40 \times 6 \mathrm{~mm}$ coverslips in $6 \times \frac{5}{8}$ soda glass tubes. These were fixed in acetone for 10 minutes, dried at room temperature, treated with dilutions of antiviral sera for 30 minutes at $36^{\circ} \mathrm{C}$, and washed well in three changes of phosphate-buffered saline at $p \mathrm{H} 7 \cdot 3$. They were then treated with fluoresceinconjugated antirabbit globulin for 30 minutes at $36^{\circ} \mathrm{C}$, washed as before with phosphate-buffered saline, rinsed in distilled water, and mounted in $70 \%$ glycerol.

The conjugate used was diluted $1: 10$ in saline and mixed with an equal volume of $0.2 \%$ naphthalene black, which masks non-specific staining. For antiserum titrations, but not for diagnostic use, the conjugate was added to dried coverslips. It was realized that this might increase background staining, but it was hoped that accuracy might be increased by avoiding an unmeasured dilution of conjugate.

\section{MICROSCOPY}

The microscope used was a Gillett and Sibert Conference microscope, with dark ground condenser and iodine quartz lamp. The primary filter was a combination of two Wratten gelatin filters nos. 32 and $38 \mathrm{~A}$ sandwiched between 2 in. square cover- glasses (Tomlinson, 1967). The secondary filter was an orange $L S / 200$. Using this filter combination fluorescence appears green and the negative background is red. Coverslips were read with a $\times 400$ magnification. Non-viral green staining ranged from a dull green background to a bright fluorescent outlining of the cells. Some of the dull green staining was probably due to a non-specific reaction (Goldman, 1968) as it was present in normal rabbit sera of dilutions $1: 4$ to $1: 16$, and was unlikely therefore to be due to an immune tissue antibody. This dull green background was more marked if coverslips were allowed to dry before the addition of the fluorescein conjugate.

These facts made objective assessment of immune tissue antibody by fluorescence very difficult, and another measure had to be found. Complement fixation was the method chosen. Conclusions from complement-fixation results were found to apply to fluorescence in that sera with high tissue antibody by complement fixation gave more green staining of uninfected control coverslips than those without, and when infected coverslips were stained with these sera specific staining could be masked by antitissue reaction. Also, significant non-viral fluorescent outlining of cells was present only with sera that had a significant complement-fixation titre against the tissue used.

ESTIMATION OF ANTIBODY LEVEL BY COMPLEMENT FIXATION AND IMMUNOFLUORESCENCE

Antibody level was estimated on serum taken eight to 15 days after each dose of virus by complement 
fixation by the method of Bradstreet and Taylor (1962). Titres of less than 1:16 were ignored as these were sometimes present in normal rabbit serum.

Normal tissue antigen was made from confluent tubes. The cell sheets were scraped off into $1 \mathrm{ml}$ of medium, treated in an ultrasonic bath for $30 \mathrm{sec}$, inactivated at $56^{\circ} \mathrm{C}$ for half an hour and used at a dilution of $1: 2$.

Viral antibody level was estimated by immunofluorescence with fourfold dilutions of serum from $1: 16$ to $1: 4,096$. The titre was taken as the highest dilution showing a definite specific fluorescence. For diagnosis the serum was used at approximately 10 times the titre.

\section{Results}

Results may be considered in two groups: first, development of unwanted antibodies to tissue used for growth of virus, and secondly development of specific antibody to virus.

ANTIBODY RESPONSE TO TISSUE

Results in Table II show that virus given in human cells intranasally or in $\mathbf{R K}_{13}$ cells by injection caused very little antitissue response. Only two estimations of tissue antibody were more than $1: 16$. The highest was 1:64 after a second intranasal dose of parainfluenza type 2 .

This is in contrast to both rabbits given mumps virus in $\mathrm{Hep}_{2}$ cells intravenously. These both produced $\mathrm{Hep}_{2}$ antibodies after one dose, rising to titres of $1: 256$ and 1:512 after two doses of antigen $\stackrel{0}{\vec{\sigma}}$

The mumps antisera also gave high titres against. K.B. cells, another continuous human epithelia line, but not against monkey kidney and vero cells (Veros are a continuous line of African greer monkey kidney.)

These results were supported by fluorescence The respiratory syncytial and parainfluenza type 2 antisera gave satisfactory fluorescence in $\mathrm{Hep}_{2}$ and L132 cells respectively.

The mumps antiserum gave reasonable specificfluorescence on virus growing in monkey kidnew cells, but in $\mathrm{Hep}_{2}$ the specific fluorescence was్ masked by antitissue reaction.

Demonstration of virus by immunofluorescences in $\mathbf{R K}_{13}$ cells was unsatisfactory whatever the antif viral serum used because the cells were grown with rabbit serum which reacted with the fluorescein conjugated antirabbit globulin.

In addition, complement-fixation tests were carried $\overrightarrow{-}$ out using normal calf serum as antigen with the mumps antisera. One mumps antiserum had a titre. of $1: 8$ against calf serum.

SPECIFIC ANTIBODY RESPONSES MEASURED BY IMMUNOFLUORESCENCE AND COMPLEMEN FIXATION

The serum antibody responses of the rabbits to theif respective viruses measured by immunofluorescences and complement fixation are shown in Table II. $\overrightarrow{\vec{B}}$

The results show that immunofluorescence is more sensitive than complement fixation, and that in mose

\begin{tabular}{|c|c|c|c|c|c|c|c|c|}
\hline \multirow[t]{2}{*}{ Virus } & \multirow[t]{2}{*}{$\begin{array}{l}\text { Method of } \\
\text { Immunization }\end{array}$} & \multirow[t]{2}{*}{$\begin{array}{l}\text { Rabbit } \\
\text { No. }\end{array}$} & \multicolumn{2}{|c|}{$\begin{array}{l}\text { Complement-fixation } \\
\text { Titre against Cells after }\end{array}$} & \multicolumn{2}{|c|}{$\begin{array}{l}\text { Antiviral Titre by } \\
\text { Complement Fixation after }\end{array}$} & \multicolumn{2}{|c|}{$\begin{array}{l}\text { Antiviral Titre by } \\
\text { Fluorescence after }\end{array}$} \\
\hline & & & One Dose & Two Doses & One Dose & Two Doses & One Dose & Two Doses \\
\hline $\begin{array}{l}\text { Parainfluenza type } 1 \\
\text { Parainfluenza type } 2\end{array}$ & $\begin{array}{l}\text { Intranasal } \\
\text { Intranasal } \\
\text { Intranasal }\end{array}$ & $\begin{array}{l}1 \\
2 \\
3\end{array}$ & $\begin{array}{l}<16 \\
<16 \\
<16\end{array}$ & $\begin{array}{r}<16 \\
<16 \\
64\end{array}$ & $\begin{array}{r}16 \\
<16 \\
<16\end{array}$ & $\begin{array}{l}64 \\
16 \\
64\end{array}$ & $\begin{array}{r}<16 \\
64 \\
256\end{array}$ & $\begin{array}{r}256 \\
256 \\
1,024\end{array}$ \\
\hline Parainfluenza type 3 & $\begin{array}{l}\text { Intranasal } \\
\text { RK I/V }\end{array}$ & $\begin{array}{l}4 \\
5\end{array}$ & $\begin{array}{r}16 \\
<16\end{array}$ & $\begin{array}{r}<16 \\
32\end{array}$ & $\begin{array}{l}<16 \\
<16\end{array}$ & $\begin{array}{l}3 \\
32 \\
32\end{array}$ & $\begin{array}{r}64 \\
64\end{array}$ & $\begin{array}{r}256 \\
256\end{array}$ \\
\hline Respiratory syncytial & $\begin{array}{l}\text { Intranasal } \\
\text { Intranasal }\end{array}$ & $\begin{array}{l}6 \\
7\end{array}$ & $\begin{array}{l}<16 \\
<16\end{array}$ & $\leq 16$ & $\begin{array}{l}<16 \\
<16\end{array}$ & 256 & $\begin{array}{l}64 \\
64\end{array}$ & $\begin{array}{c}1,024 \\
-\end{array}$ \\
\hline Respiratory syncytial & $\begin{array}{l}\text { RKI/V' } \\
\text { RK I/V' }\end{array}$ & $\begin{array}{l}8 \\
9\end{array}$ & $\begin{array}{l}<16 \\
<16\end{array}$ & $\begin{array}{l}<16 \\
<16\end{array}$ & $\begin{array}{l}16 \\
16\end{array}$ & $\begin{array}{r}64 \\
128\end{array}$ & $\begin{array}{l}64 \\
16\end{array}$ & $\begin{array}{l}256 \\
256\end{array}$ \\
\hline Adeno type 5 & $\begin{array}{l}\text { RK I/Vi } \\
\text { RK I/Vi }\end{array}$ & $\begin{array}{l}10 \\
11\end{array}$ & $\begin{array}{l}<16 \\
<16\end{array}$ & $\begin{array}{l}<16 \\
<16\end{array}$ & $\begin{array}{l}64 \\
16\end{array}$ & $\begin{array}{l}512 \\
512\end{array}$ & $\begin{array}{l}256 \\
256\end{array}$ & $\begin{array}{l}4,096 \\
1,024\end{array}$ \\
\hline Herpes simplex & $\begin{array}{l}\text { RK I/Vi } \\
\text { RK I/Vi }\end{array}$ & $\begin{array}{l}12 \\
13\end{array}$ & $\begin{array}{l}<16 \\
<16\end{array}$ & $\begin{array}{r}<16 \\
16\end{array}$ & $\begin{array}{l}<16 \\
<16\end{array}$ & $\begin{array}{r}64 \\
256\end{array}$ & $\begin{array}{l}1,024 \\
1,024\end{array}$ & $\begin{array}{l}1,024 \\
1,024\end{array}$ \\
\hline Mumps & Hep I/V² & 14 & $\begin{array}{r}32 \\
<16^{3}\end{array}$ & $\begin{array}{r}256 \\
<16^{3}\end{array}$ & 64 & 64 & 256 & 1,024 \\
\hline & $\operatorname{Hep} I / V^{2}$ & 15 & $\begin{array}{l}64 \\
16^{3}\end{array}$ & $\begin{array}{l}512 \\
<16^{2}\end{array}$ & 64 & 128 & 256 & 1,024 \\
\hline
\end{tabular}

Table II Response of rabbits to inoculated antigen

${ }^{1}$ Virus grown in $\mathbf{R K}_{18}$ cells administered intravenously

?Virus grown in Hep, cells administered intravenously

Titre against monkey kidney cells 
cases the rabbits produced a useful fluorescent antibody level even after only one immunizing dose, whatever the route of inoculation. In only one case did the complement-fixation titre equal or exceed the fluorescent antibody level. This was following the first dose of parainfluenza type 1 when the complement-fixation titre was $1: 16$ and the fluorescent antibody level $1: 4$.

A third dose of virus was of doubtful use. Only one of seven rabbits given three doses showed a rise in fluorescent antibody level.

The adenovirus used for immunization was type 5 , and the antisera were routinely tested against antigen of types 3 and 5 representing groups 1 and 3 (Rosen, 1960). Complement-fixation titres against type 5 were consistently higher than those against type 3, but the difference by fluorescence was not marked. To date, a late serum from one rabbit has been tested by immunofluorescence against adenovirus types 1 , $2,4,6$, and 28 in addition, and found to be positive.

The herpes virus used for immunization was classified as type 1 by growth on the chorioallantoic membrane of embryonated hen's eggs. The antibody level of the herpes antisera against type 1 was usually higher than against type 2 virus, whether tested by complement fixation or immunofluorescence.

An occasional cell in some batches of monkey kidney gave a granular fluorescence with the antiserum to parainfluenza type 1 . Generally this fluorescence showed larger granules than with the parainfluenza type 1 virus. However, the serum could have been reacting with a simian virus as monkey kidney was used for growing the first dose of antigen. Cross reactions with other viruses using one serum from each group have so far all proved negative.

\section{Discussion}

This study suggests, therefore, that by relatively simple techniques it is possible to produce antiviral sera which are very satisfactory for demonstrating viral antigen in tissue culture without absorption of the final serum.

Rabbits will produce antibody against cells of a different species when these are given by injection, but the presence of antibody against one type of tissue does not mean that the serum is unsuitable for use with cells of a different species.
A limited diagnostic trial has been carried out using the antisera to respiratory syncytial virus (intranasal method), adenovirus and parainfluenza types 1, 2, and 3 (MacWilliam and Herd, 1970). This was done on nasopharyngeal aspirates from young children during an epidemic of bronchiolitis due to respiratory syncytial virus.

First attempts at immunofluorescence on the aspirate itself were difficult to interpret, but Gardner and McQuillin (1968) successfully used this method, and we have had more satisfactory results in later outbreaks. Results on infected cells in tissue culture were encouraging. Eleven specimens were positive by fluorescence for respiratory syncytial virus on the day after inoculation of the specimen and one on the third day. One adenovirus and one parainfluenza type 3 were also positive by fluorescence on the day following inoculation. These 14 specimens all grew the expected virus in tissue culture. A further 11 specimens, one with reovirus, one a herpes, and nine negative in tissue culture were negative by immunofluorescence in tissue culture using the same five sera.

Thus there was complete agreement between results by immunofluorescence and conventional methods, and diagnosis was possible one to three days after reception of the specimen.

We wish to thank the Children's Research Fund for the grant which supported this work, Professor K. R. Dumbell for his help and advice, and Dr R. G. Somerville for his initial guidance.

\section{References}

Bradstreet, C. M., and Taylor, C. E. D. (1962). Technique of complement-fixation test applicable to the diagnosis of virus diseases. Mth. Bull. Minist. Hlth Lab. Serv., 21, 96-104.

Coons, A. H., and Kaplan, M. H. (1950). Localisation of antigen in tissue cells II. Improvements in a method for the detection of antigen by means of fluorescent antibody.J. exp. Med., 91, 1-13.

Gardner, P. S., and McQuillin, J. (1968). Application of immunofluorescent antibody technique in rapid diagnosis of respiratory syncytial virus infection. Brit. med. J., 3, 340-343.

Goldman, M. (1968). Fluorescent Antibody Methods, p. 176. Academic Press, New York.

Hambling, M. H. (1966). Antibody response in guinea-pigs following intranasal inoculation of respiratory syncytial virus. J. Path. Bact., 91, 625-629.

MacWilliam, K., and Herd, S. (1970). Diagnosis of respiratory infections by an immunofluorescent technique. Lancet, 2, 102-103.

Rosen, L. (1960) Ahaemagglutination inhibition technique for typing adenoviruses. Amer. J. Hyg. 71, 120.

Tomlinson, A. H. (1967). Filters for use with an iodine-quartz lamp to excite immunofluorescence. Immunology, 13, 323-324. 